\title{
Taxonomic notes on the genus Alsidium C. Agardh, including the merging of Bryothamnion Kützing (Rhodomelaceae)
}

\author{
Gabriela García-Soto* and Juan Lopez-Bautista \\ Department of Biological Sciences, The University of Alabama, Tuscaloosa, AL 35487, USA
}

In this study, the phylogenetic relationships among the genera Alsidium C. Agardh and Bryothamnion Kützing were investigated. Phylogenetic analyses using the plastid-encoded markers $r b c \mathrm{~L}, p s b \mathrm{~A}$, and the mitochondrial barcode region (COI-5P) resolved a well-supported clade that included the species Alsidium corallinum, Bryothamnion seaforthii, and B. triquetrum. Our results indicated that taxonomic recognition of the genus Bryothamnion is not supported and two species of Bryothamnion are reallocated to Alsidium. A reexamination of the morphological definition of Alsidium is provided with an updated diagnosis of the genus and a morphology-based comparison of species that are currently circumscribed under this generic name. Furthermore, we reviewed morphological differences and similarities between Alsidium and the genus Digenea, both belonging to the tribe Alsidieae, discussing the most relevant morphological characters.

Key Words: Alsidium; Bryothamnion; Digenea; phylogenetic inference; psbA; rbcL; taxonomy

\section{INTRODUCTION}

The genus Alsidium was first formally described by C. A. Agardh (1827) based on A. corallinum, species that serves as the generitype. A total of 25 species have been described under this generic name, yet six remain as currently accepted (Guiry and Guiry 2018). The Mediterranean Sea harbors four of the currently recognized species. However except for two species that are wellrepresented, A. corallinum C. Agardh and A. helmithochorton (Schwendimann) Kützing, other species from the Mediterranean Sea, such as A. notarisium Bompard and A. vagum (Zanardini) Zanardini, remain taxonomically poorly known considering they have not been reported since their original descriptions. Two minute species of Alsidium are known to occur in the Pacific Ocean. Dawson described two species based on vegetative mate- rial, A. pacificum (Dawson 1959) from Palmyra Atoll and A. pusillum (Dawson 1963) from the Galapagos Islands. A third pacific species, Alsidium cymatophilum R. E. Norris, described by Norris (1994) based on Hawaiian collections, has been transferred to Digenea based on molecular evidence (Díaz-Tapia et al. 2017).

The genus Bryothamnion was originally described by Kützing (1843) without a generitype designation. Two species were included, B. seaforthii based on Fucus seaforthii Turner and B. lindenbergii based on Thamnophora disticha Lindenberg. Additionally, Kützing described a second genus, Physcophora, based on Fucus triangularis Turner. However, in Sp. Alg., Kützing (1849) merged Physcophora into Bryothamnion and recognized five species, three of them with a complanate habit, B. seaforthii Küt-

\section{(ब) (1) $\Theta$}

This is an Open Access article distributed under the terms of the Creative Commons Attribution Non-Commercial License (http://creativecommons.org/licenses/by-nc/3.0/) which permits unrestricted non-commercial use, distribution, and reproduction in any medium, provided the original work is properly cited.
Received January 23, 2018, Accepted June 25, 2018

*Corresponding Author

E-mail: gcgarcasoto@crimson.ua.edu

Tel: +1-205-394-8556, Fax: +1-205-348-1786 
zing, B. ramellosum Sonder, and B. linderbengii Kützing and two species with a triangular habit, $B$. triangulare and B. hypnoides. Agardh (1863) described three forms of B. seaforthii, f. fastigiata, f. disticha, and f. imbricata, based on characteristics related to the branching pattern. Bryothamnion seaforthii (Turner) Kützing was later designated by Schmitz (1889) as the type species of the genus. A sixth species morphologically similar to $B$. triquetrum was described in the 20th century as B. pacificum by Taylor (1945). Only three of the six species that have been described remain as currently recognized. Two of them, B. triquetrum and B. seaforthii, are commonly reported in tropical and subtropical regions of the Atlantic and Pacific coasts of America and several Caribbean islands (Guiry and Guiry 2018), the last species reaching South-West Asia with a record in Sri Lanka (Silva et al. 1996). B. seaforthii f. imbricatum J. Agardh remains as the only form that has been reported since the original description by Agardh (1863), and it seems to be common on limestone in the Florida Keys (Dawes and Mathieson 2008) and Cuba (Suárez 2005).

The systematic position of Alsidium and Bryothamnion within the family Rhodomelaceae was recently elucidated by Díaz-Tapia et al. (2017) providing an updated tribal classification of the family based on molecular phylogenomic evidence; these two genera and a third, Digenea C. Agardh, were assigned to the resurrected tribe Alsidieae. Furthermore, the apparent non-monophyly of Alsidium and Bryothamnion was noted by Díaz-Tapia et al. (2017); however, no formal changes to the classification were proposed at the time. Likewise, this new phylogenetic understanding of the tribal classification of Rhodomelaceae calls for the review of the morphological features between the genera of the tribe, Alsidium and Digenea. Hence, the aim of this study is to clarify the phylogenetic and taxonomic status of the genera Alsidium and Bryothamnion using molecular and morphological data. The non-monophyly problem is resolved herein by merging Bryothamnion into Alsidium. In addition, we provide an updated diagnosis of the genus Alsidium and establish a morphological comparison between this genus and Digenea.

\section{MATERIALS AND METHODS}

\section{Collections and vouchers}

Samples were either collected from several geographic locations or kindly provided dried in silica gel and / or pressed on herbarium paper. Voucher specimens are located at The University of Alabama. Collection information and GenBank accession numbers of new sequences produced in this study and sequences retrieved from the GenBank are provided in Supplementary Tables S1 \& 2 .

\section{Morphological studies}

Specimens were rehydrated and thalli portions were fixed through increasing concentrations of ethyl alcohol (from 10 to $100 \%$ ). Sections of vegetative and reproductive portions of thalli were made using a Sorvall (RMC) MT-5000 Microtome, stained with $1 \% \mathrm{v} / \mathrm{v}$ aqueous aniline blue acidified with $1 \%$ diluted $\mathrm{HCl}$ and mounted on slides with Karo Corn syrup solution (Tsuda and Abbott 1986). Prepared slides were observed and studied under an Axio Imager 2 Research Microscope (Carl Zeiss AG, Oberkochen, Germany). Image capture was carried out using an integrated camera model EOS 5D Mark III (Canon Inc., Tokyo, Japan). Photographs were edited and assembled on plates using Adobe Photoshop CC (Adobe Systems Inc., San Jose, CA, USA).

\section{Genomic DNA extraction, gene amplification, and sequencing}

Genomic DNA was extracted from dried material ground in liquid nitrogen using the cetyl trimethylammonium bromide protocol modified from Doyle and Doyle (1987). After resuspension of total DNA, viscous extractions (probably due to the presence of polysaccharides) were further purified using the Wizard Genomic DNA Purification Kit (Promega, Madison, WI, USA) according to manufacturer's instructions. Full or partial sequences of $r b c \mathrm{~L}$ and $p s b \mathrm{~A}$ were obtained following amplification protocols in Saunders and Moore (2013) using the primers F57, R753, F577, R1150, F753, and rbcLrevNEW (Freshwater and Rueness 1994, Kucera and Saunders 2012) and psbAF1, psbA600R, and psbAR2 (Yoon et al. 2002), respectively. The COI-5P fragment was amplified with a single primer combination, GAZF1 / GAZR1 (Saunders 2009) following amplification profiles in Saunders and Moore (2013). Polymerase chain reaction (PCR) reactions were prepared using either Mango Taq DNA polymerase kit (Bioline, London, UK) or the AccuStart II PCR SuperMix (Quanta Biosciences, Inc., Gaithersburg, MD, USA) following manufacturer's instructions. Amplified products were purified and sent for Sanger sequencing to Advanced Genetics Technology Center and UK Healthcare Ge- 
nomics Center (University of Kentucky, Lexington, KY, USA). Contigs were edited and assembled using Geneious R7 (Kearse et al. 2012).

\section{Alignment and phylogenetic analysis}

$r b c \mathrm{~L}, p s b \mathrm{~A}$, and $\mathrm{COI}$ sequences were individually aligned using CLUSTALW in MEGA 6 (Tamura et al. 2013) under default conditions. Selection of the nucleotide substitution models for $r b c \mathrm{~L}$ and $p s b \mathrm{~A}$ was carried out using MEGA 6. Independent maximum likelihood $r b c \mathrm{~L}$ and $p s b \mathrm{~A}$ phylogenies for the family Rhodomelaceae were estimated in RAxML (Stamatakis 2014) under the General Time Reversible model (GTR) + gamma (G) with 1,000 bootstrap replicates. A concatenated alignment of the $r b c \mathrm{~L}, p s b \mathrm{~A}$, and COI-5P was generated in Sequence Matrix (Vaidya et al. 2011). A phylogenetic tree with the concatenated data was built in RAxML under the GTR + G with 1,000 bootstrap replicates. All final trees were visualized and edited using FigTree v.1.4.2 (Rambaut 2012) and Adobe Illustrator (Adobe Systems Inc.).

\section{RESULTS AND DISCUSSION}

\section{Phylogenetic analyses}

We sampled and analyzed several specimens of the two most common species of Bryothamnion, B. seaforthii and B. triquetrum, and included in our analyses the type species of Alsidium, A. corallinum. The $r b c \mathrm{~L}$ phylogeny (Fig. 1) resolved a well-supported clade containing the two species of Bryothamnion and A. corallinum. This clade was sister to the Digenea clade, both encompassing the tribe Alsidieae, in agreement with previous results in Díaz-Tapia et al. (2017). In the $p s b$ A phylogeny (not shown), there was no support for the tribe Alsidieae and the Bryothamnion / Alsidium clade obtained low support (0.65). Likewise, the phylogenetic tree inferred from the concatenated matrix (Fig. 2) resolved the tribe Alsidieae with moderate support (0.83) and the Bryothamnion I Alsidium clade with high support (1). However, Bryothamnion appears non-monophyletic because either $B$. seaforthii (Fig. 1) or B. triquetrum (Fig. 2) clustered with A. corallinum, which calls into question their assignment to two different genera.

\section{Morphological analysis}

Morphological characterization of species of Alsid- ium. Morphological observations were made on specimens of Alsidium corallinum, B. seaforthii, and B. triquetrum and whole-mount and sectioned material was observed by light microscope. These species are characterized by having an erect, relatively large cartilaginous thalli (Figs 3A \& 4A), radially organized (Figs 3B \& $5 A)$. However, the flattened portion of $B$. seaforthii becomes bilaterally organized with distichously arranged branchlets (Fig. 4B) while they have a spiral alternating arrangement in the angular thallus of B. triquetum. The main axes and laterals are clothed with short determinate branches in an irregular pattern in A. corallinum (Fig. 3B) and regularly in Bryothamnion species (Fig. 4A). A conspicuous axial filament is evident in cross and longitudinal sections of the three species and barrelshaped cells with thick cell walls made up the axial filament (Figs 3D \& 5C). This filament is surrounded by six to eight pericentral cells (Figs 3C, 4C \& 5B), sometimes up to nine in B. seaforthii. An extensive cortication can be found throughout the thalli and in main axes and laterals, cells of outermost cortical layer are usually minute, loosely (Fig. 3E) and irregularly arranged (Figs 4D \& 5E). Trichoblasts in these species are early decidous, strongly incurved, usually poorly developed, with subspherical basal and suprabasal cells tapering sharply upwards (Figs 3G \& 5D). Tetrasporophytic specimens have stichidiumlike branchlets that are arranged axillary or spirally, with one sporangium bulging in each short fertile segment (Figs 3F, 4E \& 5F).

At present six species make up the genus Alsidium. While $B$. seaforthii, B. triquetrum and A. corallinum can be objectively compared in light of the molecular and morphological evidence, the rest remain morphologically-defined species. Provided that most species are currently comparable only in a morphological context, we reviewed all relevant phycological literature and a summary of the differences and similarities between species of Alsidium is given in Table 1. Alsidium vagum (Zanardini) Zanardini from the Red Sea and A. notarisium Bompard from the Mediterranean Sea, were originally described in the mid-1800s and have only been studied once, each probably from a single collection event. Because they were poorly described, any further morphological comparison is unfeasible and their identity remains ambiguous.

Since Dawson's original descriptions of the pacific species A. pusillum and A. pacificum, these have been mentioned in several floristic accounts (Silva et al. 1987, Tsuda et al. 2012, Tsuda and Walsh 2013, Ang et al. 2014, Phang et al. 2016). Norris (1994) examined the holotype 


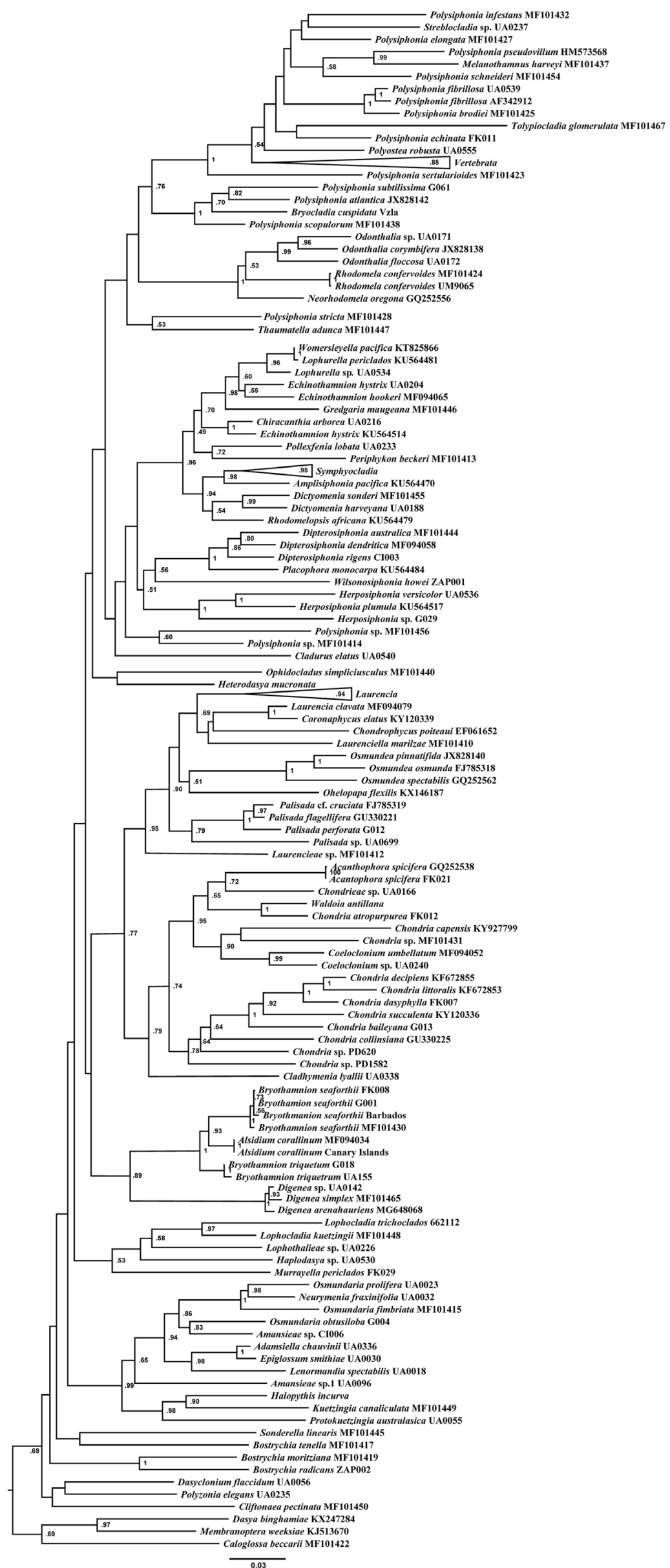

Fig. 1. Maximum likelihood phylogenetic tree estimated from the $r b c \mathrm{~L}$ gene. Values at nodes represent bootstrap support (not shown if node receive $<50$ ). 


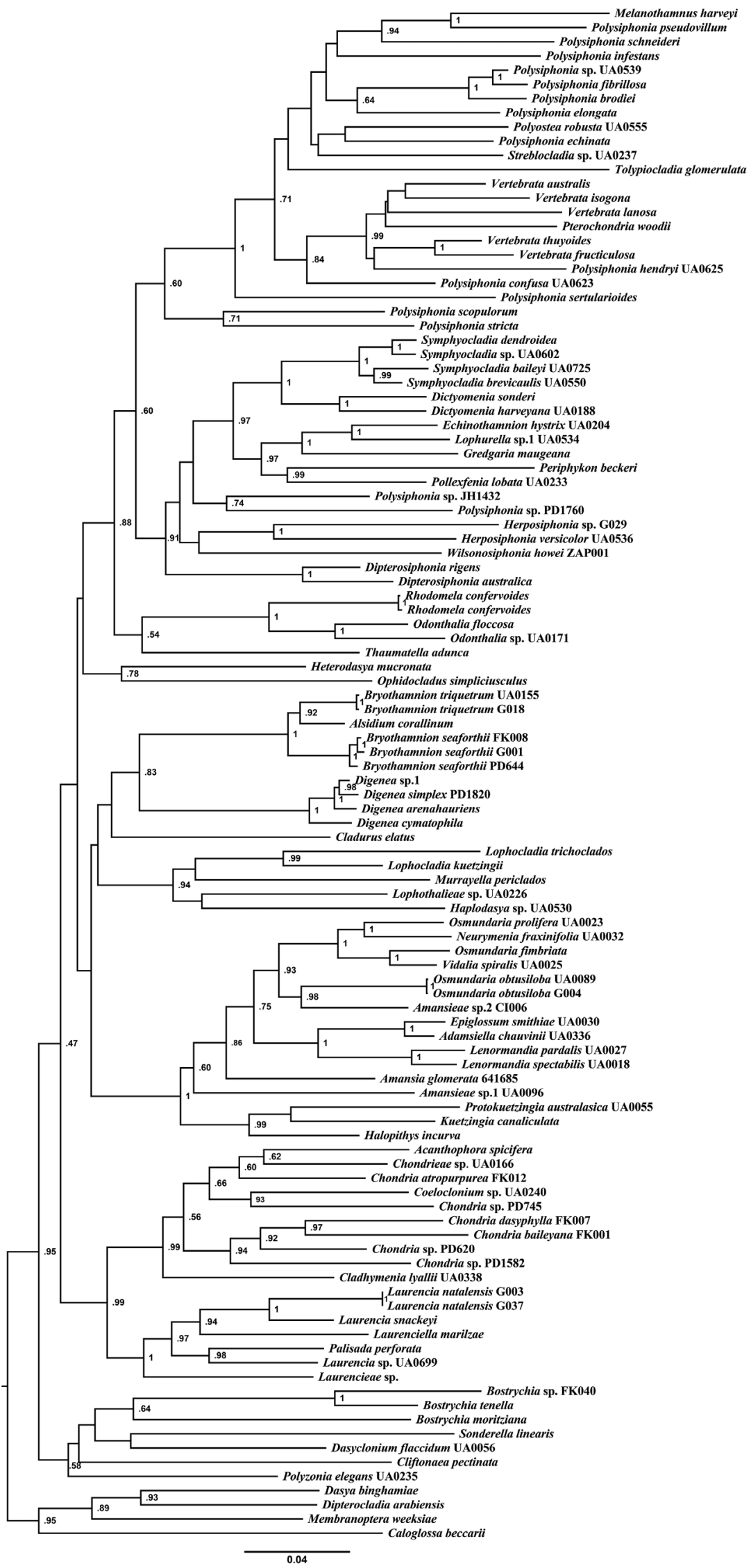

Fig. 2. Maximum likelihood phylogenetic tree of concatenated data of $r b c \mathrm{~L}+p s b \mathrm{~A}+\mathrm{COI}-5 \mathrm{P}$. Values at nodes represent bootstrap support (not shown if node received $<50$ ). 

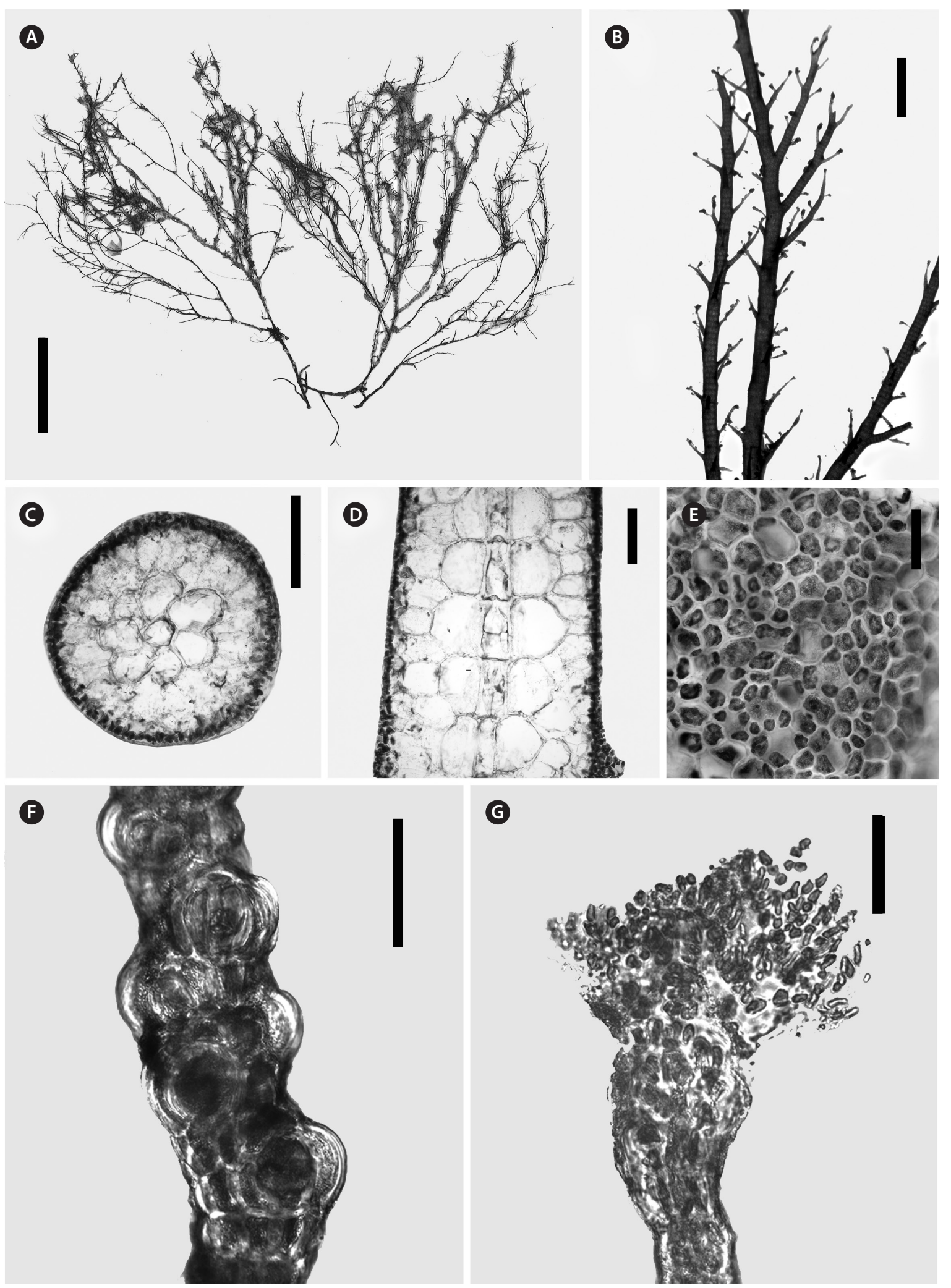

Fig. 3. Morphological features of Alsidium corallinum. (A) Habit of the thallus (dried). (B) Detail of laterals showing spirally arranged short branchlets. (C) Cross section through main axes showing axial cell surrounded by six pericentral cells. (D) Longitudinal section through main axes showing the axial filament composed of barrel-shaped cells. (E) Superficial view of thallus cortication. (F) Tetrasporangial shoot. (G) Trichoblasts. Scale bars represent: A, 2 cm; B, 2 mm; C, $500 \mu M ; D, 370 \mu M ; E, 100 \mu M ; F \& G, 50 \mu M$. 

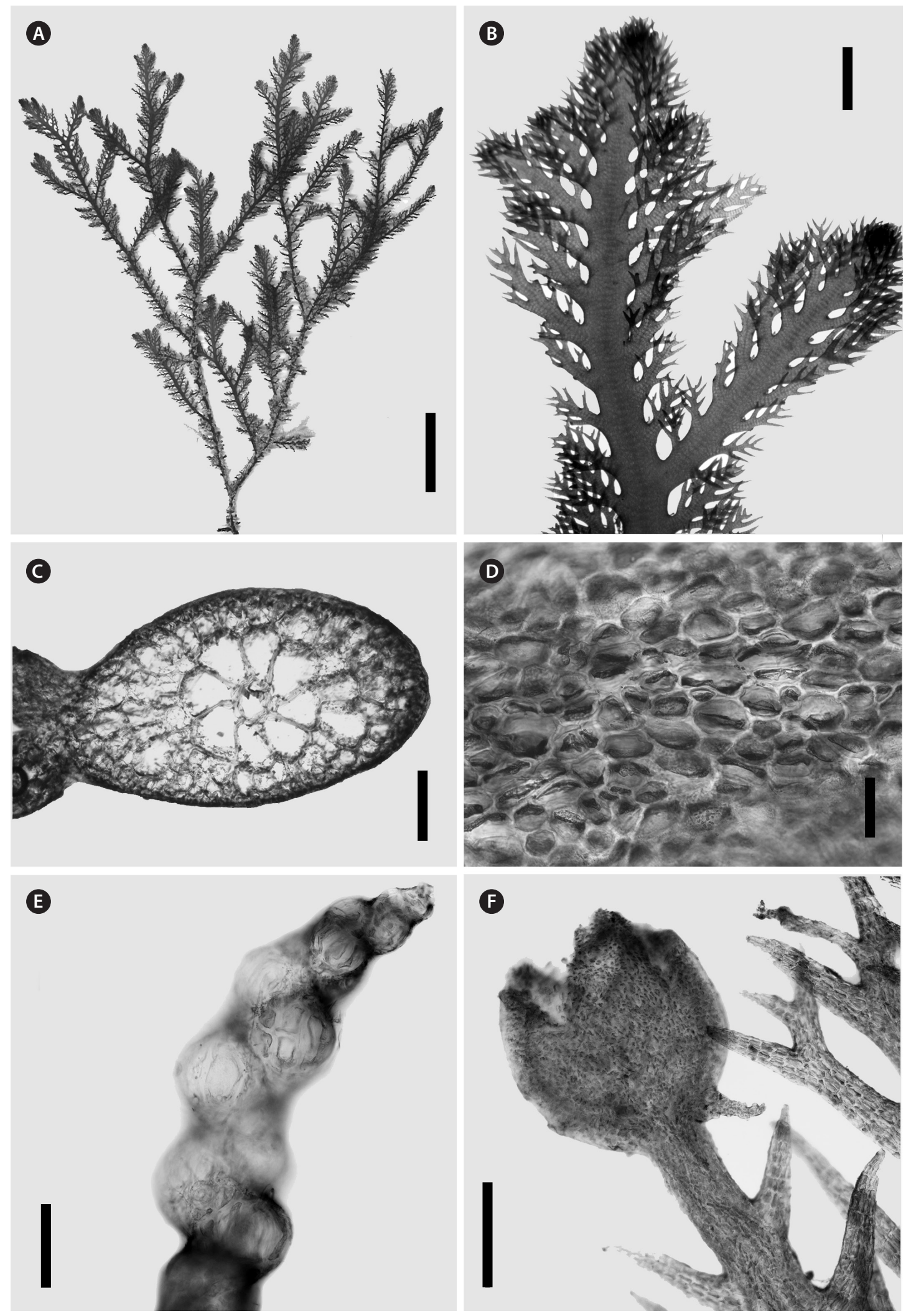

Fig. 4. Morphological features of Alsidium seaforthii. (A) Habit of the thallus (dried). (B) Detail of main laterals showing distichously arranged laterals and branchlets. (C) Cross section through main axes showing axial cell surrounded by eight pericentral cells. (D) Superficial view of thallus cortication. (E) Tetrasporangial shoot. (F) Subterminal cystocarp. Scale bars represent: A, 2 cm; B, 2 mm; C, $500 \mu M ; D, 100 \mu M ; E, 150 \mu M ; F, 300 \mu M$. 

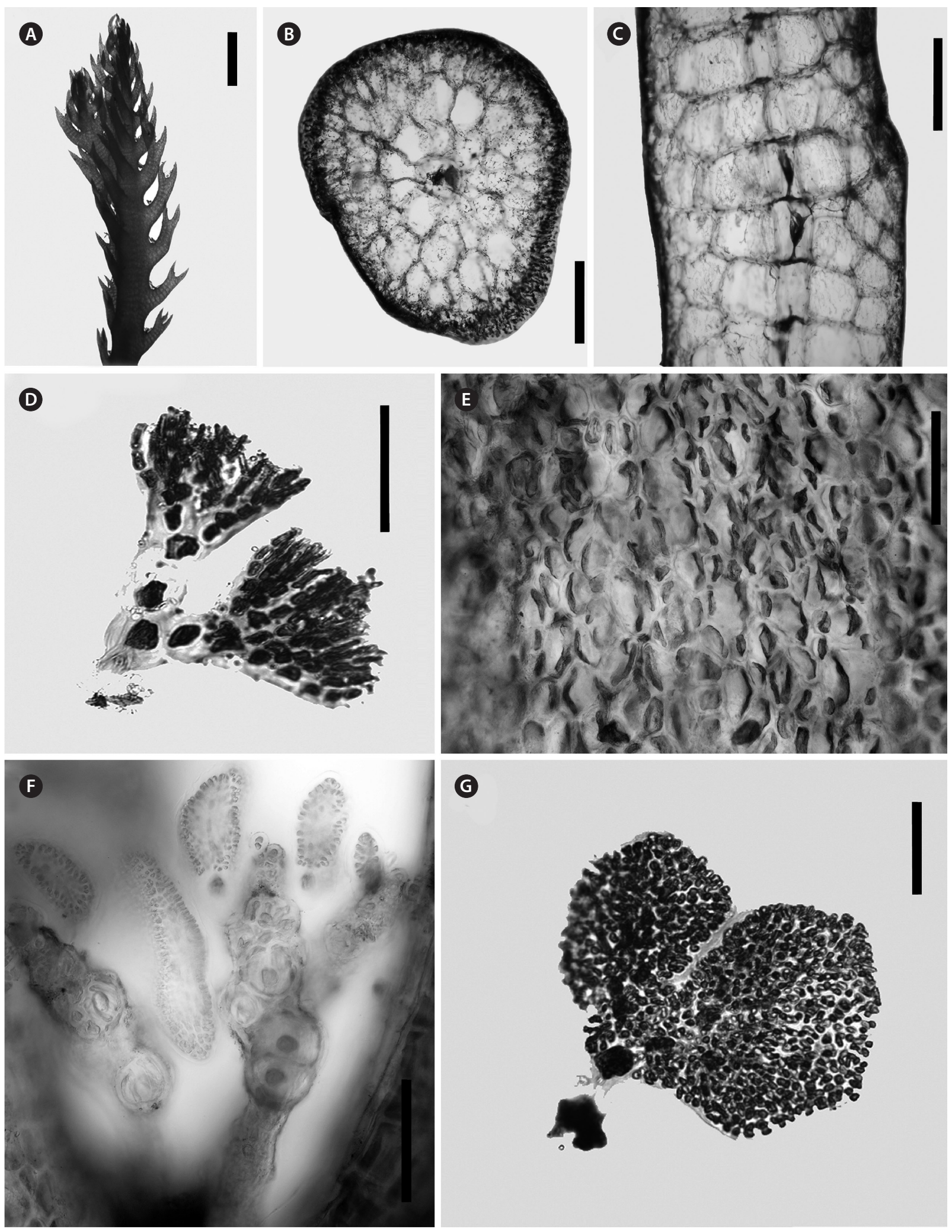

G

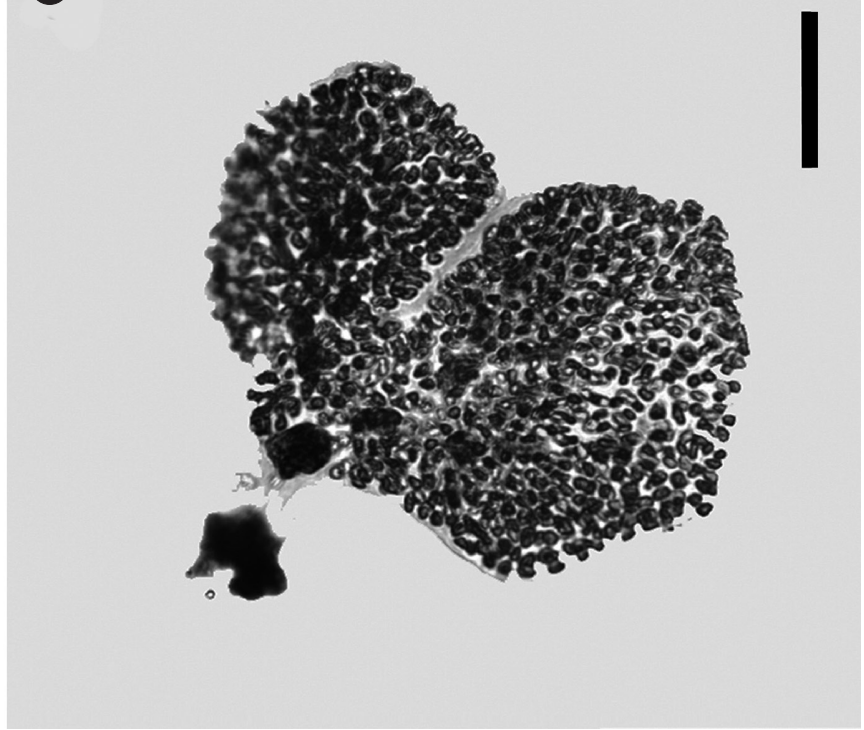

Fig. 5. Morphological features of Alsidium triquetrum. (A) Detail of laterals showing spirally arranged short branchlets. (B) Cross section through main axes showing axial cell surrounded by eight pericentral cells. (C) Longitudinal section through main axes showing the axial filament composed by barrel-shaped cells. (D) Trichoblasts. (E) Superficial view of thallus cortication. (F) Dwarf axillary shoots producing tetrasporangia and spermatangial plates. (G) Spermatangial plate. Scale bars represent: A, 2 mm; B \& C, $500 \mu M ; D \& G, 50 \mu M ; E \& F, 100 \mu M$. 


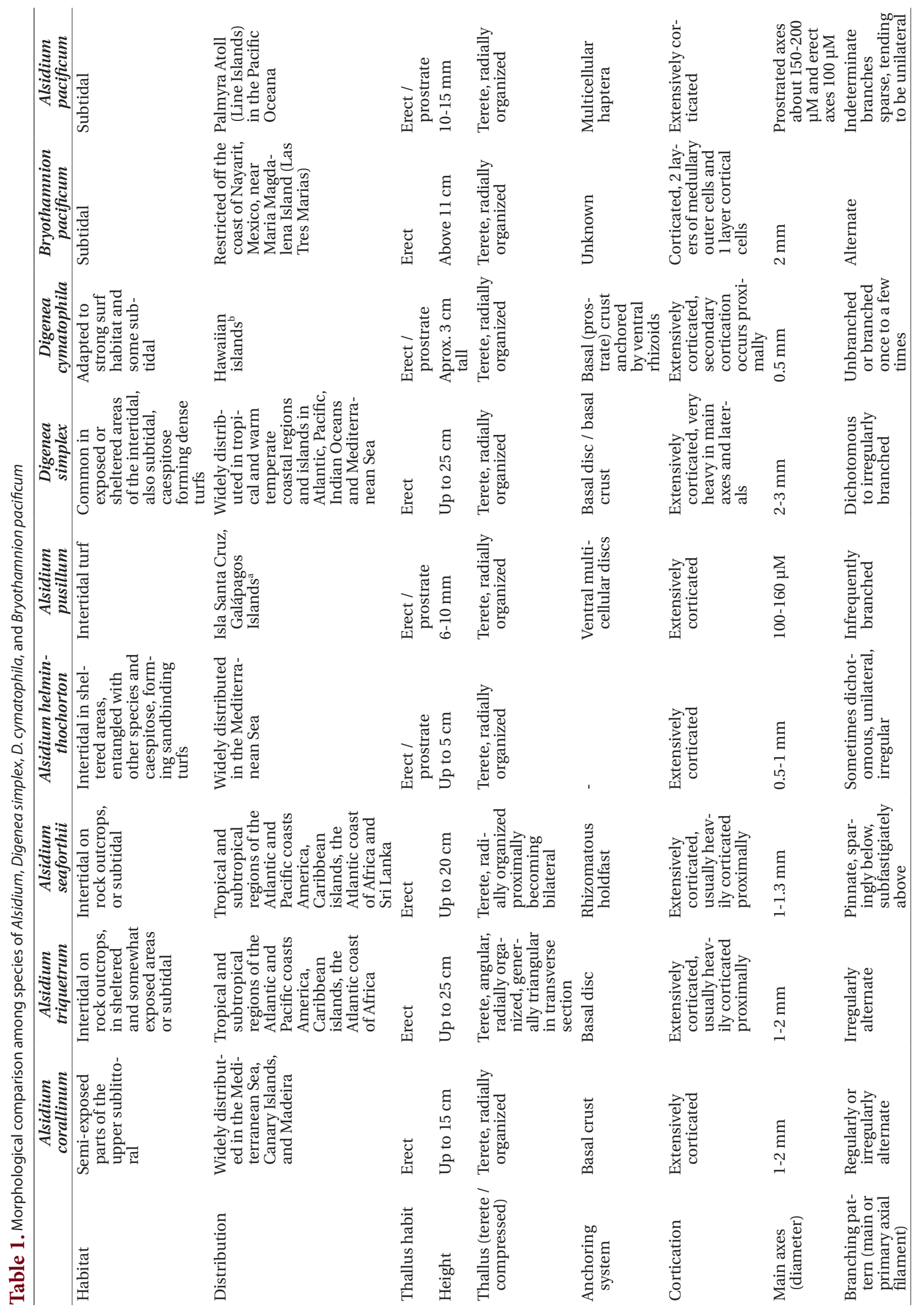




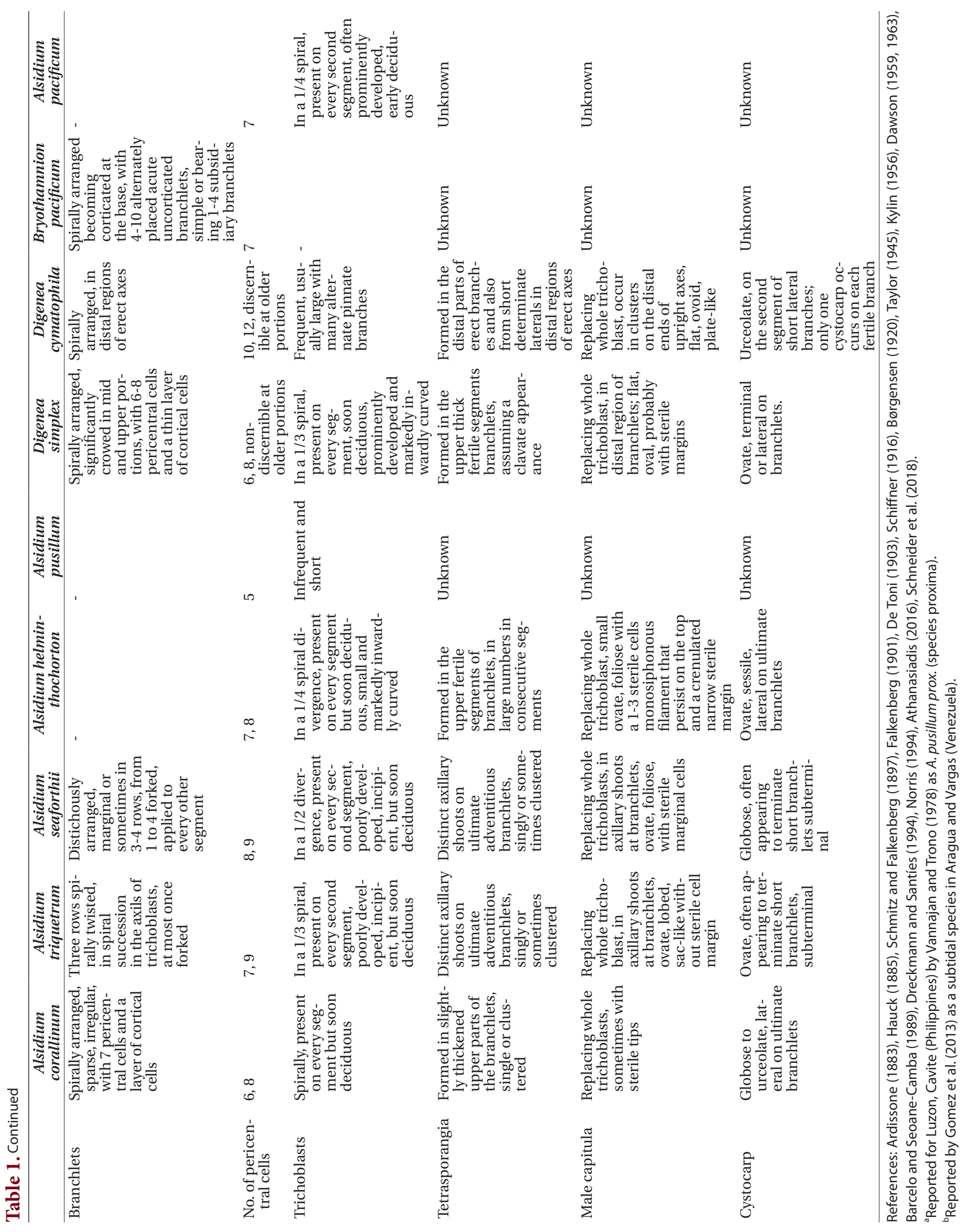


of A. pacificum and considered it cons-specific with $A$. pusillum pointing out that $A$. pacificum resembled his newly described species Alsidium cymatophilum R. E. Norris (now Digenea cymatophila) but it was ultimately different because of the lack of an encrusting base and the number of pericentral cells which are fewer in $A$. pacificum. The morphological resemblance of these species with D. cymatophila cast doubts on their current taxonomic placement as members of the genus Alsidium (Table 1).

\section{Comparison of the genera Alsidium and Digenea.}

Vegetative structure: Alsidium and Digenea are for the most part represented by coarse cartilaginous species that reach several centimeters high. Species are extensively corticated and frequently clothed with short determinate laterals. However, when internal structure is compared between the two genera, differences are evident. In Alsidium (including Bryothamnion), the axial filament is clearly evident and pericentral cells (from 6 to 9) are surrounded by 2-3 layers of large medullary cells that transition into few outermost layers of small and highly pigmented cortical cells. In contrast, in the main axes and indeterminate laterals of species of Digenea (with the exception of D. cymatophila) the axial filament is only evident right off below the apical region while remains indiscernible along the rest of the thallus. Likewise, an apical cell is not evident in longitudinal view. Several cortical layers of isodiametric cells of similar size build up the thick axes in Digenea and most species become heavily corticated throughout. The branchlets (short determinate laterals) in Digenea sharply differentiate from the main axes and are corticated by a thin layer of pigmented cells that causes the polysiphonous construction to be discernible. In contrast, determinate branches in Alsidium clearly taper sharply upwards, frequently becoming uncorticated distally. Shedding of determinate laterals is a frequently observed phenomenon. Branchlets are early deciduous in Digenea while more or less strong but also deciduous in Alsidium (Schmitz and Falkenberg 1897, Falkenberg 1901). This shedding could be related to seasonal changes (Barcelo and Seoane-Camba 1989, Cecere et al. 2002) and hervibory, being particularly evident in species of Digenea (Vidal Marques et al. 2006, Schneider et al. 2018).

Reproduction: Male capitulum: The discoid to reniform spermatangial plates is the main unifying character of the tribe Alsidieae (Fig. 5G). Flat plate-like male capitula were illustrated by Kützing (1865) for Digenea simplex and described later by Børgesen (1920) as dis- coid bodies of oblique reniform shape confirming Kützing's illustrations. Falkenberg (1901) also found analog flat antheridia in B. seaforthii. The formation of male capitula in Digenea simplex is similar to the formation in B. seaforthii. Børgesen (1920) described the process of spermatangial platesformation as follows: two cells are cut off alternately at both sides of the apical cell, these cells produce segments that remain together increasing gradually in length while dividing into smaller cells until the flat bodies are formed. We found also plates in Bryothamnion triquetrum. In our observations, aggregations of small axillary dwarf shoots produce at the same time tetrasporangia and spermatangial plates (Fig. 5F). Plates develop from the whole trichoblasts and they are discoid to slightly lobed, sometimes sac-like, with an inner network with no apparent row of sterile marginal cells and a thick outer membrane. Reproductive structures pairing in the Rhodomelaceae has been reported in several species, such as Chondria baileyana (Montagne) Harvey (Edelstein et al. 1974), Laurencia pinnatifida (Hernández-González and Gil-Rodríguez 1994) and many others from the tribes Streblocladieae and Polysiphonieae (Aguilar-Rosas and Aguilar-Rosas 1984, 2010, Cheung et al. 1984, Aguilar-Rosas et al. 2006, Díaz-Tapia and Bárbara 2013).

Spermatalgial plates of A. helminthochorton (Schwendimann) Kützing were compared to spermatangial plates of Chondria tenuissima (Withering) C. Agardh by Schiffner (1916). In Alsidium, the spermatangial plates are small egg-shaped leaflets with a 1-3 sterile cells monosiphonous filament that persist on the top of the flatten structures and a crenulated and narrow sterile margin. Through the bilateral layer of spermatia, in Alsidium, the network branches in a regular alternate fashion, while Chondria, the network is regularly dichotomous. The spermatangial plates of the latter are more rounded in outline, with a non-crenulated 2-3-cell wide sterile margin.

Tetrasporangial branches: In Agardh's definition of the tribe Alsideae, genera were separated by the morphological variation of tetrasporangia. In Alsidium and Digenea, tetrasporangia were described as being produced in simple branches, one per segment, spirally twisted, while Bryothamnion was characterized by having sporangia in axillary positioned stichidia. Kylin (1956) considered that in Bryothamnion, the sporangia were not produced in stichidia but in upper, thickened short segments. Falkenberg (1901) described Digenea as having vegetative segments about as high as wide while the fertile segments reached only one-fifth of this width. Thus, the length 
of fertile segments in Digenea is evidently reduced and some authors have described the production of sporangia in stichidia for Digenea simplex from Mexico (Dreckmann and Sentiés 1994) and Digenea cymatophila from Hawaii (Norris 1994). However, a stichidium in the strict sense is a tetrasporangial branch in which the sporangia are produced in whorls from the pericentral cells, like the ones occurring on ordinary branches in Bostrychia and the ones produced on trichoblasts in some genera of the Lophothalieae (Hommersand 1963). Agardh (1892) mentioned that Alsidium and Digenea had "stichidiis siliquaeformibus". The siliquose stichidia term is more likely referring to a very long sporangial branch, since sporangia are sometimes produced in several consecutive segments and these segments are very thickened and short. In Alsidium and Digenea, tetrasporangia are arranged in spirally twisted longitudinal rows, individually in very short fertile segments that distort and swell. However, in Bryothamnion seaforthii and B. triquetrum, fertile dwarf branches that resemble stichidia produce sporangia. These branches are axillary positioned and can be found single or clustered (Figs 4E \& 5F).

The production of kainoids: In addition to spermatangial plates, Digenea and Alsidium from the Alsidieae seem to share a chemical trait with members of the Chondrieae. Naturally derived amino acids of the kainoid type have been known to occur for several decades in some members of both tribes. Norris (1994) suggested that Alsidium and the tribe Chondrieae were phylogenetically related not only by the presence of spermatangial plates, but also by the production of domoic acid (DOM). DOM is an excitatory amino acid that exerts a neurotoxic effect (Jiang et al. 2014). It was originally isolated from Chondria armata (Takemoto and Daigo 1958) and later from Alsidium corallinum (Impellizzeri et al. 1975) and C. baileyana (Novaczek et al. 1987). Interestingly, DOM is a structural analog of kainic acid (Ramsdell and Zabka 2008), which has been isolated from Digenea simplex (Murakami et al. 1953) and Alsidium helminthocorton (Calaf et al. 1989). The latter species has been used for more than a thousand years in some parts of Asia as an anthelmintic due to the presence of this acid (Nitta et al. 1958), which produces a similar neurotoxic effect to DOM (Doucette et al. 2000).

Diagnosis of the genus Alsidium. The evidence provided by phylogenetic and morphological analyses in this study does not warrant the taxonomic recognition of the genus Bryothamnion and consequently we reallocate B. seaforthii and B. triquetrum under the generic name Alsidium C. Agardh following the Principle of Pri- ority. The merging of Bryothamnion into Alsidium calls for a new morphological interpretation of the genus and an updated morphological diagnosis of Alsidium is provided as follows:

\section{Alsidium C. Agardh, 1827}

Diagnosis: fleshy to cartilaginous erect, radially organized thalli, terete or compressed, sometimes becoming bilateral, fixed to the substrata by a basal crust or rhizomatous holdfast. Branching is exogenous, but endogenous laterals may occur. Thalli are frequently clothed with short determinate laterals, usually simple or branched once. Trichoblasts are typically small and early deciduous. Polysiphonous axis with 6 to 9 pericentral cells, cortication present throughout the thallus. Apical cell protruding. Tetrasporangia are produced 1 per segments of fertile branchlets that originate spirally or axillary. Procarps are produced on the second segment of trichoblast. Male capitulum replaces the whole trichoblast and spermatia are produced in discoid to sac-like flat plates with or without sterile margins.

Type species: Alsidium corallinum C. Agardh

New species combinations:

Alsidium seaforthii (Turner) Garcia-Soto \& Lopez-

Bautista.

Basionym: Fucus seaforthii Turner.

Taxonomic synomyn: Bryothamnion seaforthii

(Turner) Kutzing.

Alsidium triquetrum (S. G. Gmelin) Garcia-Soto \&

Lopez-Bautista.

Basionym: Fucus triqueter S. G. Gmelin.

Taxonomic synonym: Bryothamnion triquetrum

(S. G. Gmelin) M. Howe 1915.

\section{CONCLUSION}

In this study, phylogenetic analyses have provided evidence that the genus Bryothamnion is non-monophyletic. Two species of Bryothamnion, B. seaforthii (generitype) and $B$. triquetrum, are reallocated to the genus Alsidium. Successful genomic DNA extractions were limited to these two species while material of the third species of the genus, B. pacificum, failed to yield amplifiable DNA, possibly due to age-related DNA degradation. B. pacificum was described by Taylor (1945) based on sterile collections from Pacific Mexico and the striking structural resemblance with $B$. triquetrum. Since its original publication, $B$. pacificum remains poorly known and future studies may indicate that these two species 
are conspecific.

Most species of Alsidium have not been studied since they were originally described and many of the earlydescribed species are insufficiently characterized with regard to present-day requirements in species taxonomy. Consequently, many of them remain without nomenclatural verification, pointing to the possibility that some are more likely to be taxonomic synonyms with known widely distributed species while others may not even belong to the genus Alsidium. In light of this uncertainty, the challenge still remains to properly assess the taxonomic placement of these species and their phylogenetic relationships to other taxa in the Rhodomelaceae using molecular techniques.

\section{SUPPLEMENTARY MATERIAL}

Supplementary Table S1. Collection and voucher information / source of species included in the concatenated analysis including GenBank accession numbers of $r b c \mathrm{~L}, p s b \mathrm{~A}$, and COI-5P sequences (http://e-algae.org).

Supplementary Table S2. Additional species included in the phylogenetic analysis of $r b c \mathrm{~L}$ gene, collection information, references and accession numbers (http://ealgae.org).

\section{REFERENCES}

Agardh, C. A. 1827. Aufzählung einiger in den östreichischen Ländern gefundenen neuen Gattungen und Arten von Algen, nebst ihrer Diagnostik und beigefügten Bemerkungen. Flora 10:625-640.

Agardh, J. G. 1863. Species genera et ordines algarum, seu descriptiones succinctae specierum, generum et ordinum, quibus algarum regnum constituitur. Volumen secundum: algas florideas complectens. C.W.K. Gleerup, Lund, pp. 787-1138.

Agardh, J. G. 1892. Analecta algologica. Acta Univ. Lund. 28:1-182.

Aguilar-Rosas, R. \& Aguilar-Rosas, L. E. 2010. Mixed phases tetrasporangial and carposporangial on the same thallus in Polysiphonia scopulorum var. villum (Rhodomelaceae, Rhodophyta). Rev. Mex. Biodivers. 81:187-189.

Aguilar-Rosas, R., Aguilar-Rosas, L. E. \& Pedroche, F. F. 2006. Description of spermatangial thalli and mixed-phase in Polysiphonia confusa (Rhodomelaceae, Rhodophycota). Rev. Mex. Biodivers. 77:1-6.

Aguilar-Rosas, R. \& Aguilar-Rosas, M. A. 1984. Presencia de las fases carposporofita y tetrasporofita sobre el mismo talo en Polysiphonia paniculada Mont. Cienc. Mar. 10:181-183.

Ang, P. O. Jr., Leung, S. M. \& Choi, M. M. 2014. A verification of reports of marine algal species from the Philippines. Philipp. J. Sci. 142:5-49.

Ardissone, F. 1883. Phycologia mediterranea. Parte prima, Floridee. Mem. Soc. Crittog. Ital. 1:1-516.

Athanasiadis, A. 2016. Phycologia Europaea Rhodophyta Vol. II. Published and distributed by the author, Thessaloniki, pp. 763-1504.

Barceló, M. C. \& Seoane-Camba, J. A. 1989. Variació fenológica d'Alsidium corallinum C. Agardh (Rhodomelaceae: Rhodophyta) a les costes de castelló de la Plana I Alacant. Bull. Inst. Cat. Hist. Nat. 57:35-39.

Børgesen, F. 1920. The marine algae of the Danish West Indies. Part 3. Rhodophyceae (6). Dansk Bot. Ark. 3:369504.

Calaf, R., Barlatier, A., Garçon, D., Balansard, G., Pellegrini, M. \& Reynaud, J. 1989. Isolation of an unknown kainic peptide from the red alga Alsidium helminthocorton. J. Appl. Phycol. 1:257-266.

Cecere, E., Saracino, O. D. \& Petrocelli, A. 2002. Propagules of Alsidum corallinum (Rhodomelaceae, Rhodophyta). Bot. Mar. 45:580-585.

Cheung, K. W., Lee, K. Y. \& Hodgkiss, I. J. 1984. The occurrence of tetrasporangia and cystocarps on the same thalli in Polysiphonia harlandii (Rhodophyta: Ceramiales). Bot. Mar. 27:571-572.

Dawes, C. J. \& Mathieson, A. C. 2008. The seaweeds of Florida. University Press of Florida, Gainesville, FL, 656 pp.

Dawson, E. Y. 1959. Changes in Palmyra Atoll and its vegetation through the activities of man, 1913-1958. Pac. Nat. 1:3-51.

Dawson, E. Y. 1963. New records of marine algae from the Galapagos Islands. Pac. Nat. 4:3-23.

De Toni, G. B. 1903. Sylloge algarum omnium hucusque cognitarum. Vol. IV. Florideae. Sectio III. Patavii, 775-1525.

Díaz-Tapia, P. \& Bárbara, I. 2013. Seaweeds from sand-covered rocks of the Atlantic Iberian Peninsula. Part 1. The Rhodomelaceae (Ceramiales, Rhodophyta). Cryptogam. Algol. 34:325-422.

Díaz-Tapia, P., Maggs, C. A., West, J. A. \& Verbruggen, H. 2017. Analysis of chloroplast genomes and a supermatrix inform reclassification of the Rhodomelaceae (Rhodophyta). J. Phycol. 53:920-937.

Doucette, T. A., Strain, S. M., Allen, G. V., Ryan, C. L. \& Tasker, R. A. R. 2000. Comparative behavioural toxicity of domoic acid and kainic acid in neonatal rats. Neurotoxicol. Teratol. 22:863-869. 
Doyle, J. J. \& Doyle, J. L. 1987. A rapid DNA isolation procedure for small quantities of fresh leaf tissue. Phytochem. Bull. 19:11-15.

Dreckmann, K. M. \& Sentiés, G. A. 1994. El alga Digenea simplex (Ceramiales: Rhodomelaceae) en México: variación biogeográfica. Rev. Biol. Trop. 42:443-453.

Edelstein, T., Bird, C. J. \& McLachlan, J. 1974. Tetrasporangia and gametangia on the same thallus in the red algae Cystoclonium purpureum (Huds.) Batt. and Chondria baileyana (Mont.) Harv. Br. Phycol. J. 9:247-250.

Falkenberg, P. 1901. Die Rhodomelaceen des Golfes von Neapel und der angrenzenden Meeres-Abschnitte. Fauna und Flora des Golfes von Neapel, Monographie 26. R. Friedländer \& Sohn, Berlin, 754 pp.

Freshwater, D. W. \& Rueness, J. 1994. Phylogenetic relationships of some European Gelidium (Gelidiales, Rhodophyta) species, based on $r b c \mathrm{~L}$ nucleotide sequence analysis. Phycologia 33:187-194.

Gomez, S., Garcia, M. \& Gil, N. 2013. Adiciones a la ficoflora marina de Venezuela. I. Rhodomelaceae (Rhodophyta). Acta Bot. Venez. 36:183-195.

Guiry, M. D. \& Guiry, G. M. 2018. AlgaeBase. World-wide electronic publication, National University of Ireland, Galway. Available from: http://www.algaebase.org. Accessed Apr 26, 2018.

Hauck, F. 1885. Die Meeresalgen Deutschlands und Österreichs. In Rabenhorst, L. (Ed.) Kryptogamen-Flora von Deutschland, Österreich und der Schweiz. Zweite Auflage. Vol. 2. Eduard Kummer, Leipzig, pp. 513-575.

Hernández-González, M. C. \& Gil-Rodríguez, M. C. 1994. Existence of plants bearing tetrasporangia and spermatangial receptacles (mixed phases) in the genus Laurencia Lamouroux (Rhodomelaceae). Nova Hedwigia 59:189-194.

Hommersand, M. H. 1963. The morphology and classification of some Ceramiaceae and Rhodomelaceae. University of California Publications in Botany, Vol. 35. University of California Press, Berkeley, CA, 366 pp.

Impellizzeri, G., Mangiafico, S., Oriente, G., Piattelli, M. \& Sciuto, S. 1975. Amino-acids and low-molecularweight carbohydrates of some marine red algae. Phytochemistry 14:1549-1557.

Jiang, S., Kuwano, K., Ishikawa, N., Yano, M., Takatani, T. \& Arakawa, O. 2014. Production of domoic acid by laboratory culture of the red alga Chondria armata. Toxicon 92:1-5.

Kearse, M., Moir, R., Wilson, A., Stones-Havas, S., Cheung, M., Sturrock, S., Buxton, S., Cooper, A., Markowitz, S., Duran, C., Thierer, T., Ashton, B., Meintjes, P. \& Drummond, A. 2012. Geneious Basic: an integrated and ex- tendable desktop software platform for the organization and analysis of sequence data. Bioinformatics 28:16471649 .

Kucera, H. \& Saunders, G. W. 2012. A survey of Bangiales (Rhodophyta) based on multiple molecular markers reveals cryptic diversity. J. Phycol. 48:869-882.

Kützing, F. T. 1843. Phycologia generalis oder Anatomie, Physiologie und Systemkunde der Tange. FA Brockhaus, Leipzig, $458 \mathrm{pp}$.

Kützing, F. T. 1849. Species algarum. FA Brockhaus, Leipzig, $922 \mathrm{pp}$.

Kützing, F. T. 1865. Tabulae phycologicae; oder, Abbildungen der Tange. Vol. XV. Gedruckt auf Kosten des Verfassers, Nordhausen, pp. 1-36.

Kylin, H. 1956. Die Gattüngen der Rhodophyceen. CWK Gleerups Forlag, Lund, $673 \mathrm{pp}$.

Murakami, S., Takemoto, T. \& Shimizu, Z. 1953. Studies on the effective principles of Digenea simplex Ag. I. Separation of the effective fraction by liquid chromatography. J. Pharm. Soc. Jpn. 73:1026-1029.

Nitta, I., Watase, H. \& Tomiie, Y. 1958. Structure of kainic acid and its isomer, allokainic acid. Nature 181:761-762.

Norris, R. E. 1994. Some cumophytic Rhodomelaceae (Rhodophyta) occurring in Hawaiian surf. Phycologia 33:434-443.

Novaczek, I., Bird, C. J. \& McLachlan, J. 1987. Phenology and temperature tolerance of the red algae Chondria baileyana, Lomentaria baileyana, Griffithsia globifera, and Dasya baillouviana in Nova Scotia. Can. J. Bot. 65:57-62.

Phang, S. -M., Yeong, H. -Y., Ganzon-Fortes, E. T., Lewmanomont, K., Prathep, A., Hau, L. N., Gerung, G. S. \& Tan, K. S. 2016. Marine algae of the South China Sea bordered by Indonesia, Malaysia, Philippines, Singapore, Thailand and Vietnam. Raffles Bull. Zool. 34:13-59.

Rambaut, A. 2012. FigTree: Tree Figure Drawing Tool, Version 1.4.2. Available from: http://tree.bio.ed.ac.uk/. Accessed Apr 26, 2018.

Ramsdell, J. S. \& Zabka, T. S. 2008. In utero domoic acid toxicity: a fetal basis to adult disease in the California sea lion (Zalophus californianus). Mar. Drugs 6:262290.

Saunders, G. W. 2009. Routine DNA barcoding of Canadian Gracilariales (Rhodophyta) reveals the invasive species Gracilaria vermiculophylla in British Columbia. Mol. Ecol. Resour. 9(Suppl.):140-150.

Saunders, G. W. \& Moore, T. E. 2013. Refinements for the amplification and sequencing of red algal DNA barcode and RedToL phylogenetic markers: a summary of current primers, profiles and strategies. Algae 28:3143. 
Schiffner, V. 1916. Studien über algen des adriatischen Meeres. Helgol. Wiss. Meeresunters. 11:127-198.

Schmitz, F. \& Falkenberg, P. 1897. Rhodomelaceae. In Engler, A. \& Prantl, K. (Eds.) Die naturlichen Pflanzenfamilien nebst ihren Gattungen und wichtigeren Arten insbesondere den Nutzpflanzen unter Mitwirkung zahlreicher hervorragender Fachgelehrten, Teil 1, Abteilung 2. Verlag von Wilhelm Engelmann, Leipzig, pp. 421-480.

Schmitz, F. K. J. 1889. Systematische Übersicht der Bisher Bekannten Gattungen der Florideen. Flora Allg. Bot. Ztg. 72:433-456.

Schneider, C. W., Hamzeh, B. F., Lane, C. E. \& Saunders, G. W. 2018. A new species of Digenea (Rhodomelaceae, Ceramiales) based upon a molecular assessment and morphological observations of plants historically known as D. simplex in Bermuda. Phytotaxa 338:90-98.

Silva, P. C., Basson, P. W. \& Moe, R. L. 1996. Catalogue of the benthic marine algae of the Indian Ocean. University of California Publications in Botany. Vol. 79. University of California Press, Berkeley, 1259 pp.

Silva, P. C., Meñez, E. G. \& Moe, R. L. 1987. Catalog of the benthic marine algae of the Philippines. Smithson. Contrib. Mar. Sci. 27:1-179.

Stamatakis, A. 2014. RAxML version 8: a tool for phylogenetic analysis and post-analysis of large phylogenies. Bioinformatics 30:1312-1313.

Suárez, A. M. 2005. Lista de las macroalgas marinas Cubanas. Rev. Invest. Mar. 26:93-148.

Takemoto, T. \& Daigo, K. 1958. Constituents of Chondria armata and their pharmacological effects. Chem. Pharm. Bull. 6:578-580.

Tamura, K., Stecher, G., Peterson, D., Filipski, A. \& Kumar, S. 2013. MEGA6: molecular evolutionary genetics analysis version 6.0. Mol. Biol. Evol. 30:2725-2729.

Taylor, W. R. 1945. Pacific marine algae of the Allan Hancock Expeditions to the Galapagos Islands. Allan Hancock Pacific Expeditions. Vol. 12. University of Southern California Press, Los Angeles, CA, 528 pp.

Tsuda, R. T. \& Abbott, I. A. 1986. Collections, handling, preservation, and logistics. In Littler, M. M. \& Littler, D. S. (Eds.) Handbook of Phycological Methods, Ecological Field Methods: Macroalgae. Cambridge University Press, Cambridge, pp. 68-85.

Tsuda, R. T., Fisher, J. R. \& Vroom, P. S. 2012. Floristic account of the marine benthic algae from Jarvis Island and Kingman Reef, Line Islands, Central Pacific. Micronesica 43:14-50.

Tsuda, R. T. \&Walsh, S. K. 2013. Bibliographic checklist of the marine benthic algae of Central Polynesia in the Pacific Ocean (excluding Hawai'i and French Polynesia). Micronesica 2:1-91.

Vaidya, G., Lohman, D. J. \& Meier, R. 2011. SequenceMatrix: concatenation software for the fast assembly of multigene datasets with character set and codon information. Cladistics 27:171-180.

Vannajan, S. \& Trono, G. C. Jr. 1978. The marine benthic algae of Manila Bay. II. Phaeophyta and Rhodophyta. Kalikasan, Philip. J. Biol. 7:7-30.

Vidal Marques, L., Villaça, R. \& Crespo Pereira, R. 2006. Susceptibility of macroalgae to herbivorous fishes at Rocas Atoll, Brazil. Bot. Mar. 49:379-385.

Yoon, H. S., Hackett, J. D. \& Bhattacharya, D. 2002. A single origin of the peridinin- and fucoxanthin-containing plastids in dinoflagellates through tertiary endosymbiosis. Proc. Natl. Acad. Sci. U. S. A. 99:11724-11729. 